\title{
Textual analysis of the relationship between Eileen Chang and United States Information Service in Hong Kong (USIS-HK)
}

\author{
Lihui Chen \\ College of Humanism, Weinan Normal University, Weinan Shaanxi, 714000, China
}

Keywords: Eileen Chang, USIS, "The Rice Sprout Song: a Novel of Modern China", "Naked Earth".

\begin{abstract}
USIS, short for United States Information Service, is an organization established in HK by US Consulate General during the Cold War for "anti-CPC propaganda" and US policy promotion. The relationship between Eileen Chang and USIS has always been one of the most controversial issues in the studies of Eileen Chang. Through the textual research, we found that Eileen Chang who didn't hold any post in USIS just cooperated with USIS just like translator and publisher. "Naked Earth" was created under the commission of USIS. " The Rice Sprout Song: a Novel of Modern China" was a spontaneous and free creation. Since "The Rice Sprout Song: a Novel of Modern China" catered to the anti-communist standpoint of USIS, it single-handedly organized the publication of "The Rice Sprout Song: a Novel of Modern China".
\end{abstract}

\section{Introduction}

USIS, short for United States Information Service, is an organization established in HK by US Consulate General during the Cold War for "anti-CPC propaganda" and US policy promotion. Main methods for USIS to promote American culture include paying more remuneration than the local media, recruiting famous Taiwan and Hong Kong scholars to translate "Masterpieces of American literature" or buying out writers' copyright with "sky-high price" to foster anti-Communist propaganda work creation. Apart from the publications (such as "World Today" semimonthly), USIS-HK was also responsible for supporting the non-CPC-publishing industry. In the 1950s, Union Press, Life Publishing House, Zhongyi Publishing House, China Educational Supplies Corporation, Overseas Chinese Press, Tianfeng Publishing House, Dagong Publishing House, and Nanguo Publishing House have successively received funding from USIS. During her stay in Hong Kong, Eileen Chang translated a large number of literary works for USIS, published "The Rice Sprout Song: a Novel of Modern China" and "Naked Earth" in its organ publications and supporting publishing house. Therefore, the relationship between Eileen Chang and USIS has become one of the most controversial issues in the studies of Eileen Chang.

\section{Relationship details}

Yu Bin, and expert of studies of Eileen Chang, believes that "not long after she arrived in Hong Kong, she took a post in USIS. McCarthy, who was in charge, should be her top boss. They later became good friends. Apart from writing novels, what specific tasks Eileen Chang had in the organization and what specific work she had done were unknown." Yu Bin inferred from limited historical information that Eileen Chang who hold a post in USIS, but he remained his conclusions cautious and reserved on Eileen Chang's specific work. Yuan Liangjun concluded confirmatively that Eileen Chang sought refuge in USIS, "In 1952, she returned to Hong Kong from Shanghai for the name of going back to University of Hong Kong. However, after arriving in Hong Kong, instead of proceeding back to school formalities required by the university, she engaged into USIS, the anti-communist anti-china bridgehead set by CIA in Hong Kong, and abide by the command of USIS into in the countercurrent of "greenback fiction" creation (anti-communist anti-Chinese fiction)2.

Regarding the relationship between Eileen Chang and USIS, Song Qi stated in this way, "As far as I know, she translated Hemingway's "The Old Man and the Sea", and Marjorie Kinnan Rawlings's 
"The Yearling". "Emerson's Anthology" edited by Marc Van Doron, Washington's Irving's "The Legend of Sleepy Hollow," etc. It was only then that Wen Mei translated several books for the same institution in pseudonym, which was probably the reason people thought they were colleagues." 3 On June 20, 1991, Song Qi wrote in a letter to the editor of Huangguan Lifang Fang about how he got acquainted with Eileen Chang, "I worked in Department of Translation of USIS and hired with special service stating to work for a year since 1951. At that time, I worked with the head of the Ministry of Culture, Richard M. McCarthy (MJ), to rectify the stagnant Department of Translation. (I didn't translated any books in five years).... I soon received a call from the Washington News Department about the notice of getting the Chinese copyright of Hemingway's "The Old Man and the Sea." He discussed with me on how to deal with it. We agreed to take it seriously and thus public solicited translator. There were numerous applicants and Eileen Chang's name was clearly on the list. So we invited to discuss and were impressed by her authentic British English accent. She spoke slowly, very decent, then we decided to assign the translation work to her. "4

The critical person in the exchanges between Eileen Chang and Richard McCarthy, the director of the USIS. Both established a very good personal relationship. In May 2002, Gao Quanzhi interviewed 81-year-old McCarthy by telephone and e-mail. In the interview, McCarthy clarified the relationship between Eileen Chang and USIS: "Eileen was not the staff of USIS. She agreed toto provide translation services and just translated."5

Eileen Chang did not serve USIS according to So Qi and McCarthy. She just cooperated with USIS just like translator and publisher and got paid by piecework. However, the fact that Eileen Chang did not serve USIS couldn't prove the problem of "authorized work" for "The Rice Sprout Song: a Novel of Modern China" and "Naked Earth". It was this key issue which caused the ambiguity between Song Qi and McCarthy's arguments.

Song Qi as Eileen Chang's close friend and literary agent stated on "The Rice Sprout Song: a Novel of Modern China" that, "it was a complete first draft until the day she asked us to take a look" 6 Regarding "Naked Earth," Song Qi's statement was, "At this time, she was working on "Naked Earth". The outline was drafted by others instead of her free creation, which made her difficult to write." 7

McCarthy, as official who directly contacted Eileen Chang was the most reliable insider of the relationship between Eileen Chang and USIS. In 2002, McCarthy said in an interview with Gao Quan, "However, I doubted who would supported her if we didn't pay attention to her. Eileen arrived in Hong Kong in a very hard financial condition."8 Although McCarthy affirmed the story outline of "The Rice Sprout Song: a Novel of Modern China" and "Naked Earth" was written by Eileen Chang, "I know she wrote the synopsis". But he also admitted, "But we inevitably asked the progress as we supported her. She would tell us the general story and sit down to discuss with us." 9 The problem is, in which way did USIS represented by McCarthy support Eileen Chang? Was there some sort of potential mutual cooperation intention between both?

In 1995, Chen Ruoxi mentioned in the article "Eileen Chang, who focused on writing but casual for herself" that when she travelled with Eileen Chang in Taiwan for a few days in 1962.10 "After that meeting, I was still very concerned about her. In the past few years, I talked with McCarthy and wondered how she could write books like "The Rice Sprout Song: a Novel of Modern China" and "Naked Earth". McCarthy told me very proudly that Eileen Chang could complete the books in the study after they provided information." 11

Apparently, regarding the issue of whether "The Rice Sprout Song: a Novel of Modern China" and "Naked Earth" were the "authorized works" of USIS, McCarthy's statement when receiving the interview from Gao Quanzhi in 2002 was inconsistent with Chen Ruoxi's private statement privately in 1960s.

In 1971, Shui Jing said in "Cicada-A visit to Eileen Chang at night" that Eileen Chang volunteered to tell him, "Naked Earth" was written after being "Commissioned", so she was very dissatisfied because the outline of the story was already fixed. What else could be written freely by the author?" 12 Mae Fong Soong recorded quotations of Eileen Chang in the 1950s, which indirectly 
confirmed the creation of "Naked Earth": "It is resentful to write "Naked Earth" (English). The outline is stereotyped." 13

McCarthy was 81 years old when he accepted Gao Quanzhi's interview in 2002. It was very likely that the aging McCarthy mistakenly remembered the "authority" of "Naked Earth". As for Eileen Chang's own assessment of "Naked Earth", it was already clearly seen in the article "In memory of Hu Shizhi": "There is another book of "Naked Earth" written after "The Rice Sprout Song: a Novel of Modern China". To take into consideration the interest of Southeast Asian ordinary readers. I personally feel unsatisfactory. Although it was not sold as bad as "The Rice Sprout Song: a Novel of Modern China", it will not necessarily be very good. I find that accommodationist things are often the same." 14

\section{Conclusion}

Based on all the above statements, we can affirm that "Naked Earth" was created after being commissioned by USIS aiming at anti-communism propagation. The problem is that people often mention "The Rice Sprout Song: a Novel of Modern China" and "Naked Earth" together, and think that they are all under USIS's incitation.

McCarthy said when receiving Gao Quanzhi's interview, "We never tried to manipulate or 'help' the writing of "The Rice Sprout Song: a Novel of Modern China". Our meeting was short and concise. We couldn't make "The Rice Sprout Song: a Novel of Modern China" better." 15 Eileen Chang and Song Qi also strongly denied that the outline was provided by USIS. Tang Wenbiao said in the "Notes of Eileen Chang" that according to an interview with Mr. Shui Jing, the two books "The Rice Sprout Song: a Novel of Modern China" and "Naked Earth" were written after Chang was commissioned. In fact, Shui Jing clearly stated in "Cicada-A visit to Eileen Chang at night" that Eileen Chang told him initiatively that "Naked Earth" is "commissioned" for. In order to clarify the fact and avoid rumors, Lin Yiliang (Song Qi) specially wrote "Methodology of Tang Wenbiao" and angrily rebuked Tang Wenbiao. "He turned one book to two books, and "The Rice Sprout Song: a Novel of Modern China" was buried with Tang Wenbiao."16 Eileen Chang wrote a letter to show thanks to Song Qidai, "I received the brief on April 2nd, and I also saw Tang Wenbiao's Methodology" in "Union". I only flipped over his book, but also saw words about commissioned. But not for ostrichism, I won't get angry. I still cannot write a book like Stephen which is well done. This is too much for me. "17 At the same time, in the "Sayings of Eileen Chang" recorded by Mae Fong Soong, Eileen Chang said, I feel a bit relieved after asking you to look because someone can share my past feelings. The oral description can never be very clear. I would also like to see a fragment of my own book, rather than vaguely aware of an outline. When you said that you felt distressed, I was very happy -I like writing sad things and always hope to see people's tears."18 Chang also said something similar in the "The Rice Sprout Song: a Novel of Modern China", "These fragmental stories are what I can't forget. I have kept them in my heart for several years." So far I have written out and can get people to share my heavy feeling. "19 It can be seen that Eileen Chang has always believed that "The Rice Sprout Song: a Novel of Modern China" is a spontaneous and free creation rather than "commissioned".

Although "The Rice Sprout Song: a Novel of Modern China" is not a "commissioned" work of USIS, it does not mean that the creation of "The Rice Sprout Song: a Novel of Modern China" has absolutely no relation with USIS. McCarthy said in the interview by Gao Quan, "We asked Eileen to translate. She proposed to write a novel." "When starting reading the first two chapters of "The Rice Sprout Song: a Novel of Modern China", I was astonished."20 In other words, Eileen Chang was hired by USIS as a translator and took the initiative to propose writing novels. She took out the "The Rice Sprout Song: a Novel of Modern China" with two chapters finished and ask the director of USIS, McCarthy to review. Even McCarthy "never tried to manipulate or 'help' the writing of "The Rice Sprout Song: a Novel of Modern China". 21 Wasn't McCarthy with the power to publish "The Rice Sprout Song: a Novel of Modern China" showing his confidence and insinuation to Eileen Chang who was trying to open the Hong Kong market? On March 24, 1967, in a letter to Xia Zhiqing, Eileen 
Chang said, "The second edition of "The Rice Sprout Song: a Novel of Modern China" and "Naked Earth" must be approved by USIS and I have sent a letter to confirm."22 This may be the key to the problem: the bold exposure to the hardships of the people's livelihood under the rule of the Communist Party described in "The Rice Sprout Song: a Novel of Modern China" and the anti-communist political appeal of USIS chimed in easily. Thus, USIS "supported" Eillen Chang by buying out the copyright of "The Rice Sprout Song: a Novel of Modern China" at sky-high price.

It was exactly because Eileen Chang catered for USIS anti-communist standpoint when creating "The Rice Sprout Song: a Novel of Modern China", that USIS single-handedly organized the publication of the "The Rice Sprout Song: a Novel of Modern China". In 1954, the Chinese version of "The Rice Sprout Song: a Novel of Modern China" was serialized in "World Today" published by USIS. Tianfeng Publishing House which was subsidized by USIS published the separate edition. In October 1954, the Chinese version of "Naked Earth" was published by Tianfeng Publishing House. According to Eileen Chang's complaints to Mae Fong Soong and Shui Jing on USIS interference of the creation of "Naked Earth", "Naked Earth" could be the key of anti-communist propagation by USIS. However, before publishing the separate edition, it was not serialized by "World Today". Moreover, the proofreading of "Naked Earth" was messy. But no wrongly written characters were found in the part in yellow, which showed their mentality."23 The careless act was inconsistent with the style that USIS launched it as a "key" work. So what made USIS so negligent to publish " Naked Earth"? When mentioning the obstruction of publication of "Naked Earth" in Taiwan after twenty years, Ping Xintao explained, "The novel describes the communist party insulting the Kuomintang government and even ridiculed the former President Chiang Kai-shek, which made it difficult to pass the book review system at that time. Deletion of a large amount of sensitive parts would severely weaken the spirit of the original boo, so it is a real dilemma from the publisher's standpoint."24 USIS could spare all efforts on anti-communism but it not worthwhile to offend Chiang Kai-shek government, which is the reason why USIS dealt with the publication of "Naked Earth" carelessly and hastily.

\section{References}

[1] Yu Bin, "Biography of Eileen Chang", Hainan International News Publishing Center, 1993, page 256-257.

[2] Yuan Liangjun, "Legend of Eileen Chang_Literature version of historical nihilism", CULTURE JOURNAL, 2015-9

[3] Eileen Chang, Song Qi, Mae Fong Soong, "Private Sayings of Eileen Chang", Beijing October Literature Publishing House. 2011, page 22.

[4] "Private quotes of Eileen Chang", page 1.

[5] Gao Quanzhi, "Studies of Eileen Chang", Lijiang River Publishing House, 2015, page 167.

[6] "Private Sayings of Eileen Chang", page 22.

[7] "Private Sayings of Eileen Chang", page 27.

[8] "Studies of Eileen Chang", page 165.

[9] "Studies of Eileen Chang", page 166.

[10]Misdescription of Chen Ruoxi: Eileen Chang traveled to Taiwan in 1961 but Chen indeed participated the banquet held by McCarthy.

[11]Chen Ruoxi: "Eileen Chang, who focused on writing but casual for herself"; "Say goodbye to Eileen Chang", edited by Chen Zishan, Wen Hui Publishing House, 1996, page 31.

[12] Shui Jing, "Makeup for Eileen Chang", Shandong Pictorial Publisher House, 2004, page 20. 
[13]"Private Sayings of Eileen Chang", page 44.

[14]Eileen Chang, "In memory of Hu Shizhi", "Collection of Eileen Chang's Proses", Zhejiang Literature \& Art Publishing House, 1992, page 307.

[15]"Studies of Eileen Chang", page 166.

[16]Song Qi, "Methodology of Tang Wenbiao", Hong Kong Ming Pao Monthly, December 1978.

[17]"Private Sayings of Eileen Chang", page 220.

[18]"Private Sayings of Eileen Chang", page 63.

[19]Eileen Chang, "The Rice Sprout Song: a Novel of Modern China", Huangguan Publishing House, 1972, page 191.

[20]"Studies of Eileen Chang", page 166.

[21]"Studies of Eileen Chang", page 166.

[22]Xia Zhiqing, "Letter from Eileen Chang", Changjiang Literature \& Art Press, 2014, page 73.

[23]"Private Sayings of Eileen Chang", page 47.

[24]Peng Shujun, "Beautiful legend and eternal freeze-frame-Interview of Ping Xintao on Eileen Chang's work publication", refer to "Magnificence and desolation---Festschrift for Eileen Chang", Huangguan Publishing House, 1996, page 180. 